\title{
Long survival after carcinoma of the stomach
}

\author{
F. PYGOTT \\ From the Central Middlesex Hospital, London
}

EDITORIAL SYNOPSIS This paper by a radiologist is based on a follow-up of a personal series of 196 patients radiologically examined in the five-year period 1947-51. The evidence from this series suggests that with infiltration of the antrum or the antrum and body of the stomach radiological evidence of the local extent of carcinoma should not be a deterrent in considering operability.

A favourable prognosis in gastric cancer depends entirely upon successful resection and a patient's survival longer than five years from the date of positive diagnosis without resection is rare, though occasional case reports show that this may happen exceptionally. Welch and Wilkins' (1958) patient waited five years before having a carcinomatous antral polyp removed. Brown and Kane (1952) reported a six-year delay in resecting a carcinoma which had been considered inoperable, and another of their patients survived with a fundal carcinoma for seven years after a positive biopsy. One of Swynnerton and Truelove's (1952) patients survived five years without resection.

Successful resection of gastric cancer depends upon favourable operative findings, the histological character of the growth, the skill of the surgeon, and the largely unknown factor of host resistance.

There is general agreement that favourable operative findings are that the growth is limited to the stomach and that there is no serosal or local glandular extension. Many large collected series, such as those of Shahon, Horowitz, and Kelly (1956), Berkson, Walters, Gray, and Priestley (1952), Ransom (1953), Swynnerton and Truelove (1952), and of others report approximately $50 \%$ five-year survival after partial gastrectomy when no glandular involvement is present and 15 to $20 \%$ when the resected nodes have contained growth. Similar figures apply when serosal involvement is, or is not, present. It is agreed that polypoidal and ulcerative lesions have a better prognosis than infiltrative lesions of the scirrhous or encephaloid type (Steiner, Maimon, Palmer, and Kirsner, 1948; Brown, Merlo, and Hazard, 1961). This is especially true of ulcerative lesions which are macroscopically indistinguishable from simple peptic ulcers and are only recognized histologically as being in part or wholly carcinoma- tous. Blalock and Ochsner (1957) comment that $67 \%$ of their five-year survivors had ulcerative lesions compared with only $19 \%$ of those who did not survive.

The length of the clinical history and the mere size of the lesion do not, within limits, affect prognosis. Indeed, contrary to expectation, the prognosis with the so-called 'early lesion' of comparatively small size but associated with clinically related symptoms of severity enough to attract the patient's concern is on the average worse than that of the larger lesion with less clamant clinical features which presents later for diagnosis and treatment. In Balfour's (1937) large series of almost 5,000 cases from the Mayo Clinic operated upon between 1906 and 1931 those submitted to gastric resection with symptoms for a year or more had a five-year survival of $35 \%$ whereas those with symptoms for six months or less had a survival rate of $25 \%$. This experience is common to nearly all large series recorded in the literature. In any considerable series numerous instances occur of patients with a long history of probable peptic ulcer for 10 to 30 years who were submitted to partial gastrectomy for a supposed simple peptic ulcer and histologically were found to have a frankly carcinomatous ulcer or neoplastic change in some part of a simple ulcer. In such patients it is quite impossible to pinpoint any period as the onset of the neoplastic change. Although reluctant to accept the likelihood of a carcinomatous ulcer existing in the stomach for 10 to 30 years without metastasizing this is perhaps not as impossible as would appear on first reflection because the progress of carcinoma in the stomach may be very slow indeed. In three of the 60 patients of Harvey, Titherington, Stout, and St. John (1951), surviving for five years following resection, that resection was actually through carcinomatous tissue, and Walters and Tama (1961) report two patients 
who survived resections for 41 and 26 years only to die with local recurrences.

Surgically it is notable that when total gastrectomy has been required on account of the site or extent of the lesion, operation has resulted in only a small number of five-year survivals whereas subtotal gastrectomy, even when carried out with a scanty margin of normal stomach, has resulted in a much higher proportion of successes. Blalock and Ochsner (1957) comment that the poor prognosis of total gastrectomy is due to the very nature of the lesion for which the operation was needed'. Ransom (1953) reported a five-year survival of only $6.7 \%$ of patients submitted to total gastrectomy. Harvey et al. (1951) comment that 'the higher the resectability rate the less the increase in the survival rate achieved'. Ultraheroic surgery may achieve for the patient no more than a miserable short-term survival. The problem of radical total gastrectomy has recently been re-stated by Allison (1963), 26 of his 133 patients having survived five years or more.

Favourable pathological features are considered by Steiner et al. (1948) to be more easily assessed macroscopically than microscopically, and they place these features as polypoidal, non-infiltrating ulcers, infiltrating ulcers, and diffuse infiltrating lesions in order of decreasingly favourable prognosis. Balfour (1937) find's Broder's classification of value prognostically but Wilson (1961), comparing 36 patients surviving five to 10 years with a similar number who succumbed early following resection, found an equal distribution between the two series as far as this classification was concerned, and Swynnerton and Truelove's (1952) experience was similar.

Host resistance is probably the most important factor in long-term survival in cases of gastric cancer as in other sites affected by cancer. MacDonald and Kotin (1954) hold that "natural selection rather than the type or time of treatment determines resectability and curability of this disease'. It is certainly difficult to explain on any other basis reported cases of fiveyear survival following resection through carcinomatous tissue, the late local recurrences, such as those reported by Cobau, Bartlett, and Pollard (1959) 17 years after resection, Walters and Tama's (1961) cases already referred to, the patient of Steiner $e t$ al. (1948) in whom recurrence was found 22 years after resection, unless they are all regarded as cases of a second tumour occurring in a previously affected organ, as indeed a few of them may be.

It is certainly unwise to apply the term 'five-year cure' when considering survival, since there will be an appreciable number of recurrences in the five to 10 -year period. Berkson et al. (1952) quote a $31 \%$ five-year survival rate and a $23 \% 10$-year survival rate. The fact that the majority of these late recurrences are at the operative site indicate that recurrence represents a slow progress or a recrudescence in disease which has been present locally throughout the entire period following operation. It is, however, encouraging that after the 10-year period the incidence of disease in a patient who has had a resection for gastric cancer is parallel to that in the general population (Berkson et al., 1952).

Really prolonged survival of individual patients has been reported by Pack (1954), one of whose patients survived 22 years and another 20 years; by Ransom (1958), one of whose patients survived for nearly 20 years; by Dick (1952) whose patient survived for 27 years; by Sperling and Kaplan (1959) whose patients survived 21 and 23 years; and by Walters and Tama (1961) whose patients have already been referred to.

\section{REPORTED SERIES}

The study reported here is related to a personal series (Table I) of 196 patients (127 men and 69 women), who were all radiologically examined and when possible operatively treated in the five-year period ending 31 December 1951. All have been followed to their date of death or their survival, and their condition is known at the present date (January 1963).

Sixty-eight patients ( 40 men and 28 women) were not operated upon for various reasons following radiological examination. Only two of these survived two years and all were dead in less than three. Fifty-three patients (42 men and 11 women) were

TABLE I

SUMMARY OF SERIES OF 196 PATIENTS WITH CARCINOMA OF THE STOMACH

\begin{tabular}{|c|c|c|c|c|}
\hline & Males & Females & Total & Longest Survival \\
\hline Not operated upon & 40 & 28 & 68 & Two years ( 2 patients) \\
\hline Laparotomy only & 42 & 11 & 53 & Two years ( 1 patient) \\
\hline Gastro-enterostomy & 12 & 6 & 18 & Seven years ( 1 man) \\
\hline Partial gastrectomy & 27 & 15 & 42 & Five years + (1 male $)$ \\
\hline & & & & $\begin{array}{l}\text { Ten years }+(6 \text { males }) \\
\text { Five years }+(2 \text { females })\end{array}$ \\
\hline Total gastrectomy & 6 & 9 & 15 & $\begin{array}{l}\text { Ten years }+(3 \text { females }) \\
\text { Four years }(1 \text { patient })\end{array}$ \\
\hline
\end{tabular}


submitted to laparotomy alone and only one survived two years and none longer. Eighteen patients (12 men and six women) had a palliative gastro-enterostomy. Eight patients survived less than six months, three survived two years, one survived three years, and another (G.E., a man of 69 years) survived for seven years. The history of the survivor for seven years will be discussed later.

Forty-two patients ( 27 men and 15 women) had a partial gastrectomy performed. Eighteen patients succumbed within a year. Twenty patients survived for three years, and 12 of these survived five years $(29 \%)$ and nine survived 10 years $(22 \%)$. This re- presents an approximately $6.5 \%$ five-year survival rate over the whole series and a rate of about $4.5 \%$ for 10 years, not grossly dissimilar from that of other series.

Fifteen patients (six men and nine women) had a total gastrectomy. Ten did not survive a year, four survived less than two years, and only one of these survived more than four years and died of a recurrence before reaching the fifth year.

PATIENTS SURVIVING BETWEEN FIVE AND TEN YEARS Table II summarizes the history and findings in four patients, two men and two women, who survived

TABLE II

FIVE- TO 10-YEAR SURVIVORS AFTER OPERATIONS FOR GASTRIC CARCINOMA

\begin{tabular}{|c|c|c|c|c|c|c|c|c|c|c|}
\hline Sex & $\begin{array}{l}\text { Age } \\
(y r .)\end{array}$ & $\begin{array}{l}\text { Duration of } \\
\text { History }\end{array}$ & $\begin{array}{l}\text { Palpable } \\
\text { Mass }\end{array}$ & Site & $\begin{array}{l}\text { Type of } \\
\text { Growth }\end{array}$ & $\begin{array}{l}\text { Glandalar } \\
\text { Involve- } \\
\text { ment }\end{array}$ & Adherence & $\begin{array}{l}\text { Secondary } \\
\text { Carcino- } \\
\text { mata }\end{array}$ & $\begin{array}{l}\text { Cause of } \\
\text { Death }\end{array}$ & $\begin{array}{l}\text { Survival } \\
(y r .)\end{array}$ \\
\hline Female & 61 & Six mth. & No & Antral & $\begin{array}{l}\text { Scirrhous and } \\
\text { adenocarcinoma }\end{array}$ & Yes & - & - & $\begin{array}{l}\text { Local } \\
\text { recurrence }\end{array}$ & Six \\
\hline Female & 52 & Two & No & $\begin{array}{l}\text { Antral } \\
\text { and body }\end{array}$ & $\begin{array}{l}\text { Infiltrative (no } \\
\text { histology of } \\
\text { primary) }\end{array}$ & Yes & - & $\begin{array}{l}\text { Secondary } \\
\text { deposits in } \\
\text { ovary } 6 \text { yr. } \\
\text { before death }\end{array}$ & $\begin{array}{l}\text { Local } \\
\text { recurrence }\end{array}$ & Eight \\
\hline Male & 69 & Two mth. & No & Body & $\begin{array}{l}\text { Ulcerative (no } \\
\text { histology) }\end{array}$ & No & To pancreas & - & $\begin{array}{l}\text { Local spread } \\
\text { after gastro- } \\
\text { enterostomy }\end{array}$ & Five \\
\hline Male & 64 & $\begin{array}{l}\text { Thirty yr. } \\
\text { Ulcer showed } \\
\text { clinically, } \\
\text { radiologically } \\
\text { and surgically } \\
\text { for } 32 \text { years } \\
\text { before resection }\end{array}$ & No & Body & $\begin{array}{l}\text { Adenocarcino- } \\
\text { ma; at operation } \\
\text { ulcer regarded } \\
\text { as simple }\end{array}$ & No & - & - & $\begin{array}{l}\text { Coronary } \\
\text { thrombosis }\end{array}$ & Nine \\
\hline
\end{tabular}

TABLE III

TEN-YEAR SURVIVAL AFTER OPERATION FOR GASTRIC CARCINOMA

\begin{tabular}{|c|c|c|c|c|c|c|c|c|c|}
\hline $\begin{array}{l}\text { Age } \\
\text { (yr.) }\end{array}$ & $\begin{array}{l}\text { Duration of } \\
\text { History }\end{array}$ & $\begin{array}{l}\text { Palpable } \\
\text { Mass }\end{array}$ & Site & Type of Growth & $\begin{array}{l}\text { Glandular } \\
\text { Involve- } \\
\text { ment }\end{array}$ & Adherence & $\begin{array}{l}\text { Secondary } \\
\text { Carcinomata }\end{array}$ & $\begin{array}{l}\text { Cause of } \\
\text { Death }\end{array}$ & $\begin{array}{l}\text { Survival } \\
\text { (yr.) }\end{array}$ \\
\hline
\end{tabular}

Succumbing from other causes after 10 years

\begin{tabular}{|c|c|c|c|c|c|c|c|c|c|c|}
\hline \\
\hline Female & 60 & $\begin{array}{l}\text { Forty years' } \\
\text { dyspepsia, } 10 \\
\text { mth. severe }\end{array}$ & No & Antral & Adenocarcinoma & No & No & $\begin{array}{l}\text { Sigmoid } \\
\text { colon }\end{array}$ & $\begin{array}{l}\text { Carcinoma } \\
\text { sigmoid colon }\end{array}$ & 11 \\
\hline Male & 60 & One year & Yes & Antral & Anaplastic & No & No & - & $\begin{array}{l}\text { Pulmonary } \\
\text { tuberculosis }\end{array}$ & 10 \\
\hline \multicolumn{11}{|l|}{ Still alive } \\
\hline Female & 56 & One year & No & $\begin{array}{l}\text { Antrum } \\
\text { and body }\end{array}$ & $\begin{array}{l}\text { Small-celled } \\
\text { anaplastic }\end{array}$ & No & $\begin{array}{l}\text { To transverse } \\
\text { colon }\end{array}$ & - & - & 12 \\
\hline Female & 66 & One year & Yes & Antral & $\begin{array}{l}\text { Adenocarcinoma } \\
\text { and simple ulcer }\end{array}$ & No & To pancreas & & - & 12 \\
\hline Male & 57 & One year & No & $\begin{array}{l}\text { Antral } \\
\text { and body }\end{array}$ & Scirrhous & No & $\begin{array}{l}\text { Greater } \\
\text { omentum }\end{array}$ & - & - & 13 \\
\hline Male & 60 & $\begin{array}{l}\text { Eighteen years' } \\
\text { ulcer, dyspepsia, } \\
1 \text { year severe }\end{array}$ & Yes & $\begin{array}{l}\text { Antral } \\
\text { and body }\end{array}$ & Adenocarcinoma & No & $\begin{array}{l}\text { Mesocolon } \\
\text { and mesentary }\end{array}$ & $\begin{array}{l}\text { Carcinoma } \\
\text { splenic flexure } \\
\text { carcinoma } \\
\text { ascending } \\
\text { colon }\end{array}$ & $\bar{e}$ & 14 \\
\hline Male & 43 & $\begin{array}{l}\text { Six-seven years' } \\
\text { ulcer, dyspepsia, } \\
\text { severe two or } \\
\text { three years }\end{array}$ & No & Antral & $\begin{array}{l}\text { Chronic peptic } \\
\text { ulcer with ana- } \\
\text { plastic carcinoma } \\
\text { in base }\end{array}$ & No & No & - & - & 12 \\
\hline Male & 36 & $\begin{array}{l}\text { Three or four } \\
\text { years }\end{array}$ & No & Antral & Scirrhous & No & $\begin{array}{l}\text { Peritoneum } \\
\text { lesser sac }\end{array}$ & - & - & 11 \\
\hline Male & 60 & $\begin{array}{l}\text { Fifteen years, } \\
\text { two years } \\
\text { severe }\end{array}$ & No & $\begin{array}{l}\text { Antral } \\
\text { and body }\end{array}$ & $\begin{array}{l}\text { Medullary with } \\
\text { scirrhous change }\end{array}$ & $\begin{array}{l}\text { Yes, } \\
\text { limited }\end{array}$ & No & - & - & 11 \\
\hline
\end{tabular}




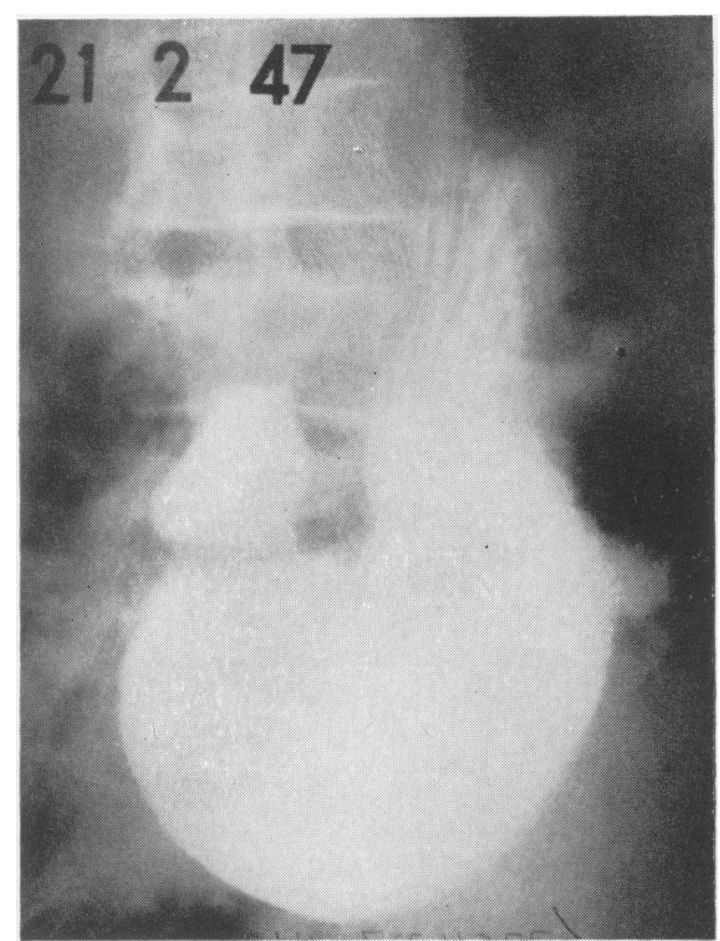

FIG. 1. Radiograph of man of 69 years with a small 'gastric ulcer' of the angulus.

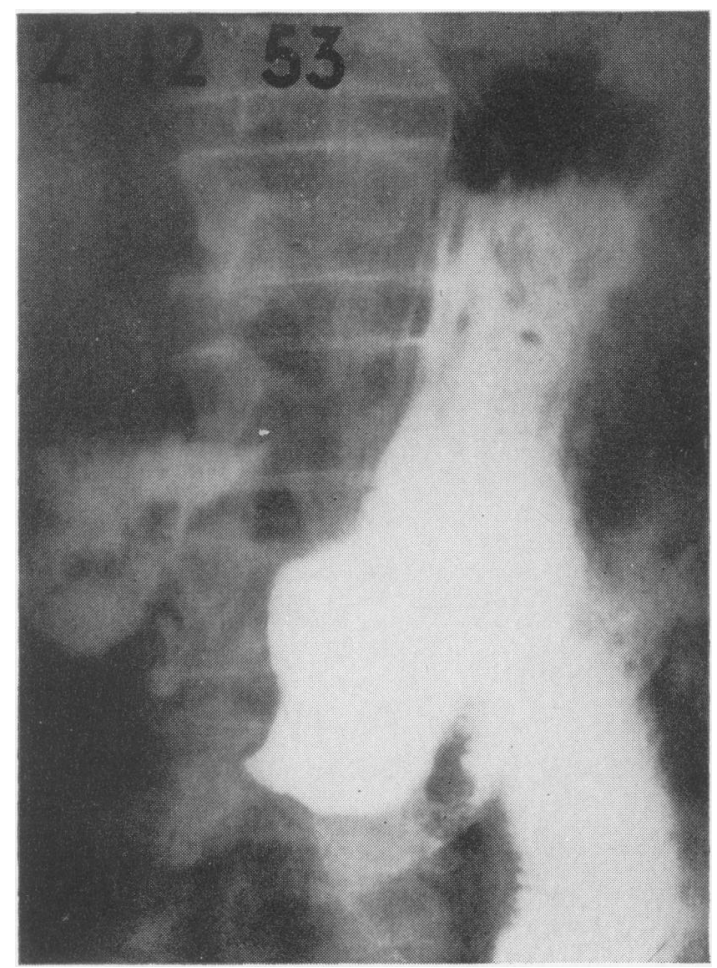

FIG 3. Same patient as Fig. 1 four years after operation virtually free of symptoms. Gastric antrum is grossly deformed.

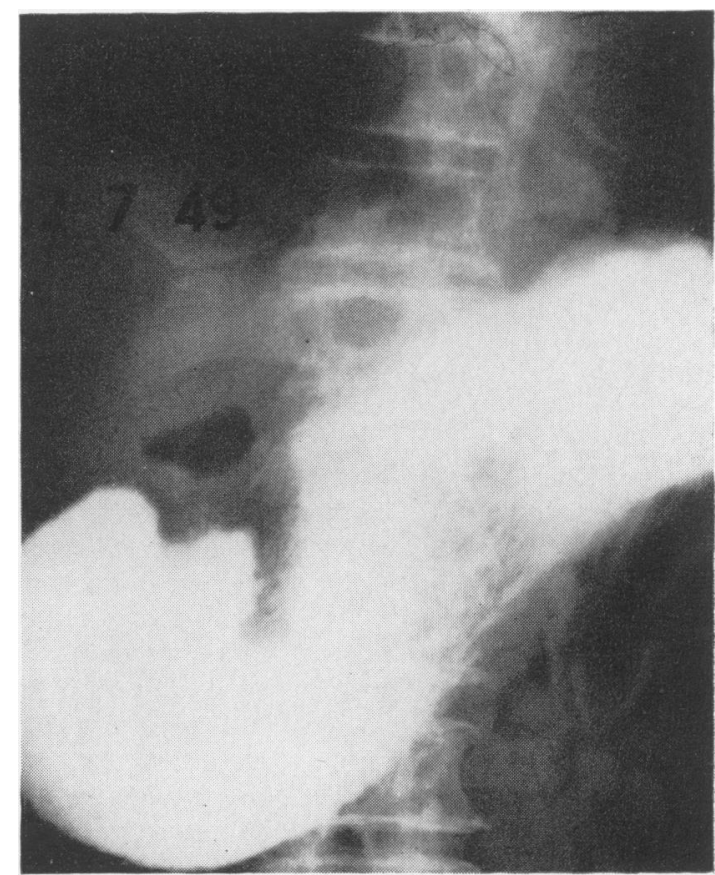

FIG. 2. Same patient as Fig. 1 two and a half years later showing a large ulcer shortly before palliative gastroenterostomy.

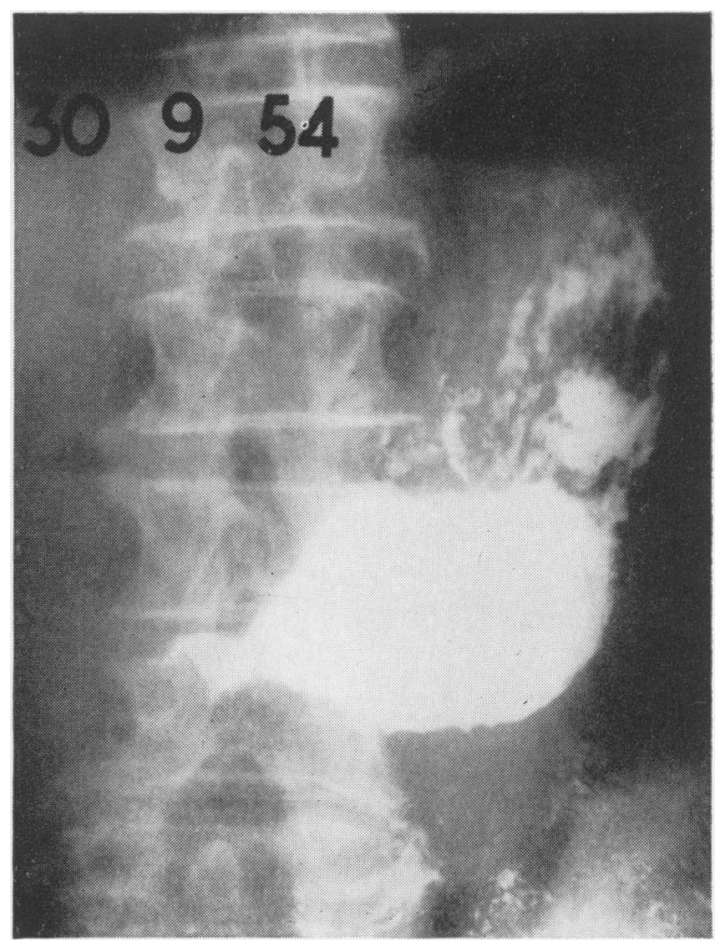

FIG. 4. Same patient as in Fig. 1 shortly before death showing rapid alteration in appearances of the stomach in nine months from those shown in Figure 3. The gastroenterostomy stoma is obstructed by growth. 
between five and 10 years from the date of operation. Both women died of local recurrences of the tumour, the younger six years after the removal of both ovaries which were involved by Krukenberg tumours of the size of a coconut. The man of 69 years is of particular interest since he had only a palliative gastro-enterostomy and yet survived over seven years from the date of his first radiological examination (Figs. 1-4).

PATIENTS SURVIVING 10 YEARS OR MORE Table III summarizes the history and findings in nine patients, three women and six men, who survived for more than 10 years from the time of resection of a tumour. None had a clinical history of less than a year and in five (one woman and four men) it was impossible to distinguish any precise onset of new symptoms from a much longer history of dyspeptic pain and discomfort extending over many years. In three patients a palpable mass was present. In none of the survivors could the growths be described as early, and the growths had spread locally in five patients, one woman requiring a partial colectomy and another a partial pancreatectomy. Despite the local extent of

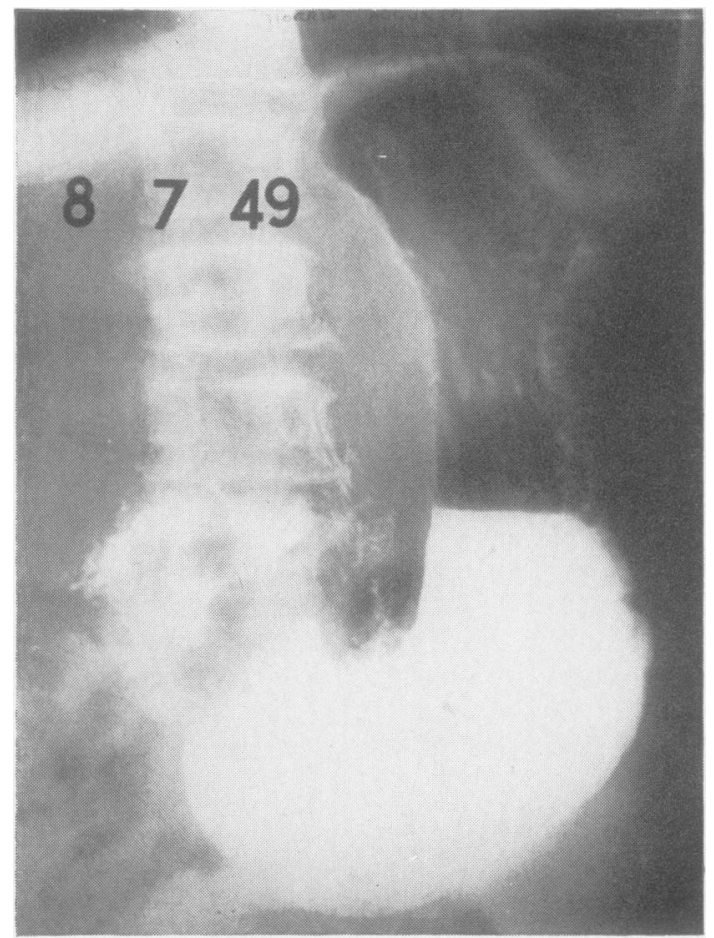

FIG. 5. Radiograph of a woman of 66 years in whom a barium meal showed gross antral deformity with an ulcer crater in the antrum. Laparotomy soon afterwards was thought to show a healed ulcer. the lesions there was only one survivor who had histological evidence of glandular metastases and in him the extension was very limited. One woman developed a carcinoma of the sigmoid colon eight years after gastric resection and died of this 11 years after partial gastrectomy despite resection of the colonic neoplasm. One man died of pulmonary tuberculosis 10 years after gastric resection and at necropsy there was no evidence of any tumour remaining. There is a possibility that his late development of tuberculosis may be connected with the partial gastrectomy, as Balint (1958) has shown that deaths from pulmonary tuberculosis following this operation are about three times the normal expectation.

Seven patients (two women and five men) are still alive, the two women 12 years after partial gastrectomy and the men 11 to 14 years after resection. The stories of two of these patients will be given in some detail as the first illustrates some of the difficulties of diagnosis and the second the cancer proneness and cancer resistance of some long survivors.

Mrs. A. M. was 66 when she presented on 8 July 1949

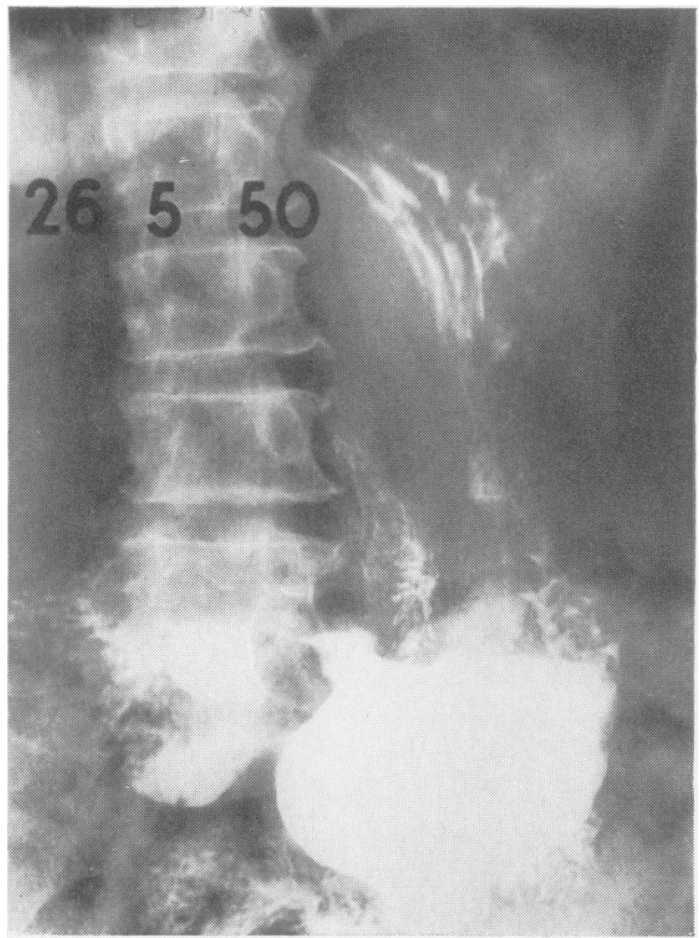

FIG. 6. Same patient as in Fig. 510 months later showing substantially similar appearances, yet laparotomy showed an ulcer penetrating the pancreas (adenocarcinoma). Alive and well 12 years later. 
with symptoms of abdominal pain for one year occurring about an hour after meals in bouts every three or four weeks. She had recently lost 1 stone in weight. She had had a history of peptic ulcer for six in the past commencing 17 years before. A palpable mass was present in the epigastrium. A barium meal showed deformity and contraction of the pyloric antrum with an ulcer crater in it (Fig. 5). Laparotomy was performed on 4 August but the findings were thought to be compatible with a healed antral ulcer and no further action was taken. The patient did not improve and a barium meal on 26 May 1950 (Fig. 6) showed no substantial change in the appearance. On 8 June laparotomy was again performed and an ulcer was found penetrating into the pancreas with hard nodules round it. The subpyloric lymph glands were enlarged. Partial gastrectomy was performed with removal of part of the head of the pancreas. Histology showed a simple ulcer, and lateral to it adenocarcinoma infiltrating the muscular coat but not reaching the ulcer; the lymphatic glands were not involved. The patient recovered and is alive and well 12 years after partial gastrectomy and 13 years after the original diagnosis.

Mr. E. L. was aged 60 when first examined on 6 September 1948 . He gave a long history of 18 years of indigestion and pain but symptoms had become continuous in the past year with pain, loss of energy, and loss of 1 stone in

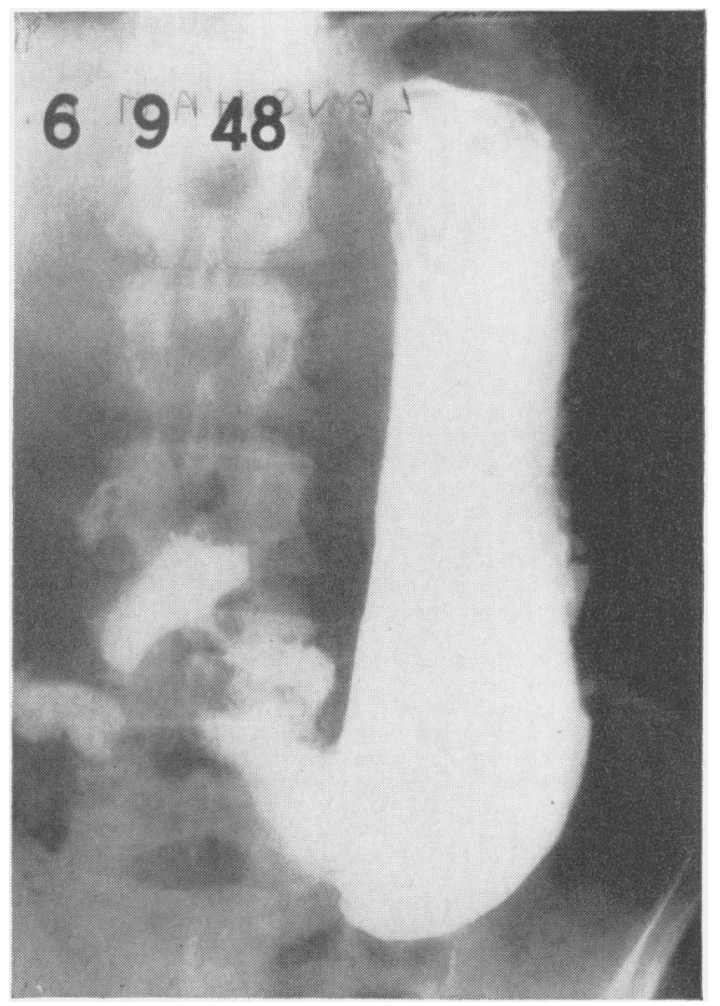

FIG. 7. Radiograph of a man of 60 years with an extensive antral carcinoma. Alive and well 14 years after partial gastrectomy. weight. An epigastric mass was palpable. A barium meal showed a large, irregular filling defect involving the antrum and distal part of the body of the stomach (Fig. 7). Laparotomy on 21 September revealed a carcinomatous ulcer on the greater curvature infiltrating the peritoneal coat and adherent to the mesocolon and mesentary. A high partial gastrectomy was performed with removal of some lymphatic glands on the lesser curvature which were thought to be involved. Histology showed an adenocarcinoma but the lymphatic glands were not infiltrated. The patient made a good recovery, but in May 1955 he presented with abdominal pain and vomiting. Laparotomy on 23 June showed a carcinoma of the splenic flexure (histologically confirmed) and this was resected. Obstructive symptoms recurred and laparotomy on 13 September revealed a ring carcinoma of the ascending colon (histologically confirmed) and this too was removed. It is significant that no histological evidence of glandular involvement was found in association with any of this patient's three carcinomata. He is alive and well 14 years after partial gastrectomy and seven years after the second partial colectomy.

\section{DISCUSSION}

Approximately $20 \%$ of the patients had a partial gastrectomy and of these $28 \%$ survived for five years and $21 \%$ survived for 10 years. One patient, who had had only a palliative gastro-enterostomy, survived seven years from the recognition of the ulcer (carcinoma) and for five years after the anastomosis. No patient who had had a total gastrectomy survived more than four years. Cancer proneness is illustrated by the occurrence of three carcinomas in two of the patients who survived 10 years.

Among the long survivors it is of interest to consider what effect delay in diagnosis had on the outcome. In the five-year survivors clinical and radiological suspicions were not aroused for two and a half years in one man whose laparotomy convinced the surgeon of the neoplastic nature of the condition. In the other man in this group evidence at laparotomy failed to convince the surgeon of any significant abnormality being present nearly six months after the diagnosis of a gastric ulcer, and even three years later still the exploring surgeon was unable to satisfy himself of the simplicity or otherwise of the nature of the lesion he was removing and yet this patient survived nearly 10 years to die of a coronary thrombosis. Among the 10-year survivors a 'negative' laparotomy was followed by the removal of a surgically obvious carcinoma nine months later in one of the women. In one of the men a 'gastric ulcer' was observed for 20 months before a surgically 'simple' pre-pyloric ulcer was removed. It is clear that host resistance is one of the biggest factors in long survival and that this can compensate at times 
quite remarkably for the fallibility of the clinician, radiologist, and surgeon severally or in combination.

The series illustrates the importance of local containance of the neoplasm. Of the four five-to 10 -year survivors, three died with local recurrence or extension of the tumour, and in two glands were involved at the time of resection when examined histologically. Among the 10-year survivors, only one man of the nine patients had any glandular involvement histologically at the time of the resection and this was very localized; in two more instances the surgeon at operation thought that lymphatic glands were involved but the histological findings were negative.

It is quite impossible to assess the degree of difficulty encountered surgically in removing the growth from the patients who survived yet it is clear that in two of the 10-year survivors an extensive and difficult dissection was required to remove a locally fixed tumour which had involved adjacent structures such as the transverse colon, mesocolon, or mesen-

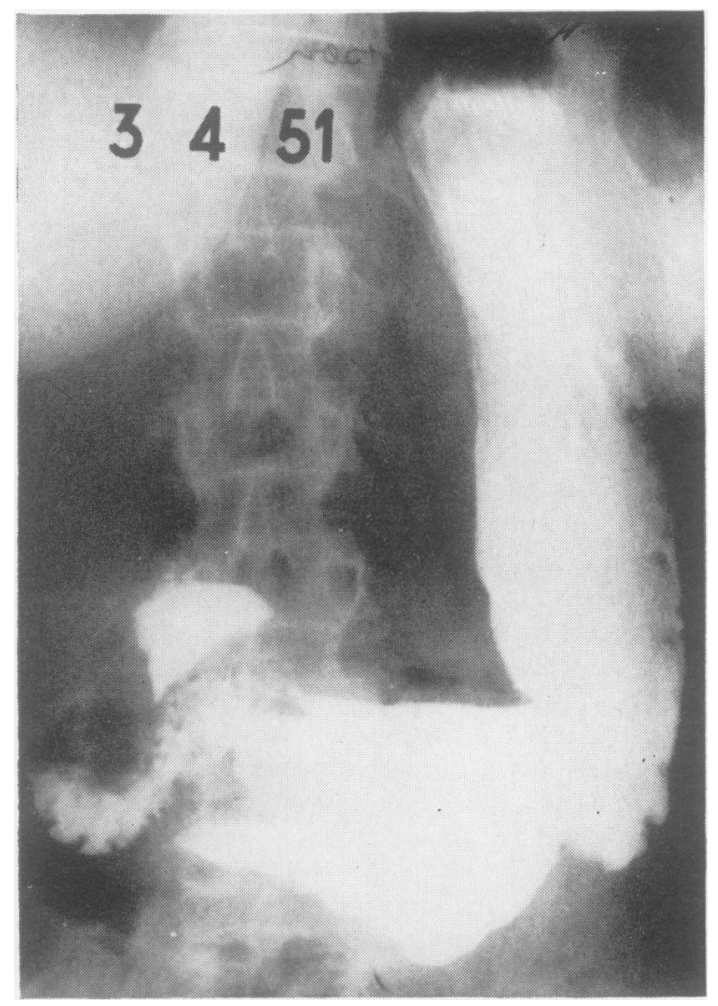

FIG. 8. Radiograph of a woman of 56 years. A barium meal and laparotomy showed extensive involvement of the distal half or more of the stomach by growth (anaplastic carcinoma). Partial gastrectomy with removal of part of transverse colon. Alive and well 12 years later. tery, In such instances it must have seemed to the surgeon that his efforts were unlikely to be as successful as the outcome proved to be.

In the long survivors the type of growth encountered showed quite a range histologically with four adenocarcinomata, three anaplastic, two scirrhous, and two mixed cell carcinomas. The numbers are too small to form a firm basis for opinion but it seems that the type of tumour is of less importance than the other factors discussed, of which host resistance appears the most influential in determining survival.

Concluding, it appears that the prognosis in resectable gastric cancer is closely comparable to that of carcinoma of the breast or uterus. Success depends not so much upon the extent of the local disease but upon the absence of glandular and of course remote metastases. The evidence from the series certainly suggests that, provided gastric involvement is antral or confined to the antrum and body of the stomach, radiological evidence of its local extent should not be considered a deterrent factor in considering a patient's operability (Fig. 8).

I wish to acknowledge the assistance given to me by my clinical colleagues, especially Dr. F. Avery Jones, Mr.T. G. I. James, Mr J. D. Fergusson, Mr. J. W. P. Gummer, Mr. F. A. Henley, and Professor H. Hashemian. I am also particularly indebted to Miss B. White, who gave great assistance with the early part of the follow-up while patients, still alive, were numerous. I am also obliged to Mr. A. Booker for the reproductions of the radiographs.

\section{REFERENCES}

Allison, P. R. (1963). Radical total gastrectomy for carcinoma of the stomach. Lancet, 1, 1014-1016.

Balfour, D. C. (1937). Factors of significance in the prognosis of cancer of the stomach. Ann. Surg., 105, 733-740.

Balint, J. A. (1958). Pulmonary tuberculosis and partial gastrectomy. Gastroenterologia (Basel), 90, 65-84.

Berkson, J., Walters, W., Gray, H. K., and Priestley, J. T. (1952). Mortality and survival in cancer of the stomach. A statistical summary of the experience of the Mayo Clinic. Proc. Mayo Clin., 27, 137-151.

Blalock, J., and Ochsner, A. (1957). Carcinoma of the stomach. A study of 18 five-year survivors. Ann. Surg., 145, 726-737.

Brown, C. H., and Kane, C. F. (1952). Carcinoma of the stomach. Review of 406 cases seen from 1940 to 1945: operability, resectability and curability. Gastroenterology, 22, 64-79.

_ Merlo, M., and Hazard, J. B. (1961). Clinical study of five-year survivors after surgery for gastric carcinoma. Ibid., 40, 188-196.

Cobau, C. D., Bartlett, R. J., and Pollard, H. M. (1959). Recurrent carcinoma of the stomach seventeen years after subtotal gastrectomy. Ibid., 37, 427-433.

Dick, E. T. (1952). Long term survival following partial gastrectomy for carcinoma of the stomach. N.Z. med. J., 51, 417 .

Harvey, H. D., Titherington, J. B., Stout, A. P., and St. John, F. B. (1951). Gastric carcinoma. Experience from 1916 to 1949 and present concepts. Cancer (Philad.), 4, 717-725.

MacDonald, I., and Kotin, P. (1954). Biologic predeterminism in gastric carcinoma as the limiting factor of curability. Surg. Gynec. Obstet., 98, 148-152.

Pack, G. T. (1954). Cancer of the stomach: twenty year cures. Surgerv, $35,920-924$.

Ransom, H. K. (1953). Cancer of the stomach. Surg. Gynec. Obstet., 96, 275-287. 
Ransom, H. K. (1958). In Discussion of Welch and Williams Paper. Ann. Surg.,148, 679-680.

Shahon, D. B., Horowitz, S., and Kelly, W. D. (1956). Cancer of the stomach. An analysis of 1,152 cases. Surgery, 39, 204-221.

Sperling, L., and Kaplan, L. (1959). Factors in long-term survival of carcinoma of the stomach. Two case reports of 21- and 23-year survival. Amer. Surg., 25, 976-985.

Steiner, P. E., Maimon, S. N., Palmer, W. L., and Kirsner, J. B. (1948). Gastric cancer; morphological factors in five-year survival after gastrectomy. Amer. J. Path., 24, 947-969.
Swynnerton, B. F., and Truelove, S. C. (1952). Carcinoma of the stomach. Brit. med. J., 1, 287-292.

Walters, W., and Tama, L. (1961). Long-term survival of carcinoma of the stomach following partial gastrectomy. Minn. Med., 44, 52-55.

Welch, C. E., and Wilkins, E. W., Jr. (1958). Carcinoma of the stomach. Ann. Surg., 148, 666-681.

Wilson, R. (1961). Longevity in gastric cancer. Canad. J. Surg., 4, 293-297. 